\title{
A Discursive Psychological Framework for Analysing Men and Masculinities.
}

Margaret Wetherell and Nigel Edley

Forthcoming - Psychology of Men and Masculinity

\section{Abstract}

This paper aims to describe and promote a Discursive Psychological approach to studying men and masculinity. It begins by showcasing some of our own research in this area, before moving on to compare and contrast the central tenets of this approach with those underpinning one of the mainstays of North American scholarship on men and masculinity: the Gender Role Strain Paradigm. We argue that, despite significant points of overlap, Discursive Psychology differs from the Gender Role Strain Paradigm in several key respects; including its treatment of variability, its theory of ideology and its model of the social actor. We claim that, in line with the precepts of Discursive Psychology, gender researchers need to pay closer attention to the nuances of men's talk and to see masculinities as practical accomplishments, rather than the (inevitable) playing-out of particular role prescriptions. 


\section{A Discursive Psychological Framework for Analyzing}

\section{Men and Masculinities ${ }^{1}$.}

\section{Margaret Wetherell and Nigel Edley}

\section{Forthcoming - Psychology of Men and Masculinity}

This paper aims to outline and advocate a discursive psychological framework for the investigation of men and masculinities, in part, by showcasing some of our own research within this area of gender scholarship. The selected studies come from a collaboration that began in the 1990s (Edley \& Wetherell, 1995; 1996; 1997; 1999; 2001; 2008; Wetherell \& Edley, 1998; 1999; 2008 - see also Edley, 2001; 2002; 2006; Wetherell, 1996; 1998; 2003) and which has since been applied, developed and critiqued by researchers mostly in the UK, but also in Australia, South Africa, New Zealand, Scandinavia, Switzerland and the USA (e.g. Dixon \& Wetherell, 2003; Frosh et al., 2000; 2002; Gill et al., 2005; Gough, 2009; Gough \& Robertson, 2009; Hall \& Gough, 2011; Hall et al., 2012; Henwood \& Proctor, 2003; Henwood et al., 2001; Korobov, 2004; Korobov and Bamberg, 2004; Nentwich, 2008, Phoenix \& Frosh, 2001; Riggs, 2010; Seymour-Smith, 
2008; 2013; Seymour-Smith \& Wetherell, 2006; Seymour-Smith et al., 2002; Speer, 2005; Staunaes, 2005; 2009; Terry \& Braun, 2009;

2011; 2013; Toerin \& Durrheim, 2001; Weatherall, 2002).

Discursive psychology differs from more traditional psychological approaches in placing language, or discourse, centre-stage. Whist, in the past, psychologists have typically treated language as a resource, providing clues as to what is going on inside people's minds or brains, discursive psychology takes language as its central topic, examining the ways in which people talk about - or construct - things like identities, attitudes, and emotions (e.g. Antaki \& Widdicombe, 1998; Potter \& Wetherell, 1987; Edwards, 1997). Discursive psychology aims to capture the paradoxical relationship that exists between discourse and the speaking subject. It recognizes that people are, at the same time, both the products and the producers of discourse (Billig, 1991) and it aims to examine, not only how identities are produced on and for particular occasions, but also how, in the form of established 'repertoires' or ways of talking, history or culture both impinge upon and are transformed by those performances. 
With respect to masculinities, a discursive psychological approach focuses on how they are routinely 'done' or accomplished (West \& Zimmerman, 1987; 2009). Discursive psychology treats masculinity, not as an essence to be revealed, but as sets of variable practices that are actively developed and negotiated in relation to other forms of identity in particular cultural contexts. Such practices take many different forms and involve a wide range of activities; such as the disciplining of bodies to match currently ideal physiques, choices of clothes and fashion, leisure pursuits, gendered hierarchies in workplaces, and so on. Our particular interest is in the discursive patterns which lie at the heart of these everyday practices. We investigate men's narratives, accounts and interactions. We focus on the making of meaning around masculinity, taking a qualitative rather than a quantitative approach.

In terms of the structure of this paper, we will begin with two brief examples of our research to indicate the general approach, the kinds of patterns we find as we look at men's accounts of themselves and their activities, and the theory we deploy to interpret these patterns. We will then go on to compare our approach with what we see as being the dominant North American paradigm in the psychology of 
men and masculinities; that is, forms of quantitative research (frequently psychometric) guided by versions of role theory (Cochran 2010; Levant \& Richmond, 2007).

\section{Jockeying for Position}

The material chosen as our first example comes from an ethnographic-styled investigation of young middle-class masculinity based in the UK (Edley \& Wetherell, 1997). This analysis was particularly concerned with exploring the operation of 'hegemonic masculinity'. The concept of hegemonic masculinity was developed by Carrigan, Connell \& Lee (1985) to acknowledge, first, that masculinities are plural rather than singular and, second, that different kinds of masculinities are constructed in relation to, and through struggles with, each other. We wanted to examine the relationships between privileged forms of masculine identity and other, less exalted, alternatives, to see how they play out 'on the ground'. The data came from a series of semi-structured interviews conducted with three groups of boys who were all attending the same single-sex school. The nine boys involved were between 17 and 18 years of age and were in post-compulsory education, studying $A^{\prime}$ 
('Advanced') Levels - in preparation for going to University. Each group of three was interviewed on eight separate occasions, across a nine month period, with the sessions taking place on the school premises during school hours. All of the participants were volunteers whose anonymity was guaranteed through the use of pseudonyms. The interviews covered a broad range of topics, including daily activities, family and relationships. The over-riding aim was to create an informal atmosphere in which, to a large extent, the participants could dictate the direction and flow of the conversation.

One of the first major topics to emerge in these interviews concerned the internal divisions of their own school year or cohort. Participants described how their year was divided into several antagonistic clusters, but with one group at its centre: the rugby players. The modus operandi of this particular group was clearly macho. During break-times, for example, they would take over the common room with rough and tumble games, forcing everyone else out on to the margins. The rugby players were widely regarded as the 'hard' lads, and without doubt their ascendant position was held in place, in part at least, by the threat of physical violence. But the dominance of this group was also underpinned by formal structures operating within 
the school. Like many institutions of this type, an 'honours' system gave particular prominence to sporting success -the rugby (and cricket) players went around wearing distinctively coloured blazers. Moreover, the rugby players were heavily over-represented in terms of positions of authority such as head boy, house captains and prefects. In no uncertain terms the school gave its 'stamp of approval' to a particular (i.e. macho) way of being.

Yet the material we examine below comes, not from this hegemonic or dominant group, but from a different set of students. In the first extract, we join the action where one of the participants is attempting to describe the character of his particular circle of friends (see Appendix for the transcription conventions).

AARON: With our group I think it'd be fair to say, it would be the easiest group to join (.) whereas to be in the rugby group would be hard (.) I mean if you want to or not (.) I mean I wouldn't but you'd have to (.) it's all very chauvinistic and male and all that stuff (.) to get in there you'd have to like be 'ard and get kicked about a bit 
This small stretch of data underscores the argument put forward by Edward Said (1978) that people often gain a sense of their own identities through a process of contra-distinction. Who we are is defined in terms of who we are not. Secondly, as Carrigan et al. (1985) argued, for men the key comparisons are not only with women / femininities but also between alternative forms of masculinity.

One fascinating feature of Aaron's account concerns the way he constructs the macho masculinity of the rugby players; he describes them as 'all very chauvinistic and male' (our emphasis). This, we would suggest, is a clear illustration of hegemony in action. Here we can see the naturalization of macho masculinity; it is glossed as just the way men are. Of course, it's not in Aaron's best interests to invoke this equation, as it leaves him in a precarious position. Under such conditions, if he is to distinguish himself (and his friends) from the rugby players, he must locate himself outside of being male. Indeed, this is precisely what we find in the accounting of another member of the same friendship group: 
NEIL: [...] whereas they'd probably see themselves as men and I'd probably see myself as a person rather than a man (.) well I am a man (.) I don't know

Neil is caught here in what discursive psychologists call an ideological dilemma (Billig, Condor, Edwards, Gane, Middleton \& Radley, 1988). It is as if he wants to identify as a man but, at the same time, finds it difficult - because of the strict equation of maleness and machismo. There's a palpable sense here of Neil struggling to find some kind of resolution; trying to find a way of creating an alternative identity for himself.

Connell (1995) argues that whilst gay masculinity stands as the most conspicuous of subordinate masculinities, there are other identities that are also 'expelled from the circle of legitimacy' (p. 79), including the 'wimp'. Interestingly, this was an identity that was explicitly claimed by Neil in a later interview. In the extract reproduced below, we see the interviewer (NE) inviting him to elaborate on this unusual identification. 
NE: Okay there was something you said Neil that just interested me there (.) you said erm that you described yourself as a erm pacifist (.) wimp (1.0) do you really see yourself as a wimp? NEIL: Oh yeah (1.0) yeah because (2.0) I've got this theory that em (1.0) I'm ss (.) I don't do anything (.) I'm scared of getting hurt (.) I mean I suppose everybody is but er (1.0) yeah I do I mean er if a wimp (1.0) a wimp (2.0) if a wimp's somebody who'll back down from a fight or won't get into them (.) and is seen as being (.) you know (.) physically less able (.) then that's fine (.) I'm happy with that

KEITH: There's nothing wrong with being a wimp is there? (laughter) It stops you getting beaten up [laughing]

It is significant, first of all, that Neil declares himself 'scared of getting hurt'. As many commentators have testified (e.g. Brannon, 1976; Seidler, 1989), hegemonic masculinity involves the repudiation of such 'soft' emotions; so here we have a concrete example of Neil constructing himself as Other. But, at the same time, there are also some clear signs of resistance. Upon admitting feeling scared, he immediately suggests that such fears are universal, rather than just particular to him, thereby rendering the fortitude of the rugby 
players an act of mere bravado. Secondly, Neil frames this entire account as a theory, rather than a straightforward description of his own constitution, which mitigates or weakens the epistemological status of such a troubled identity. And yet, in spite of these defensive manœuverings, just moments later, Neil re-enters the discussion in an effort to re-fashion himself afresh.

NEIL: Actually (.) just thinking like that I think you know a wimp is probably not just physically (.) I think people who are mentally weak as well (.) and I don't think I'm mentally weak as in I can't stand up for myself verbally or you know (.) or perhaps a wimp's someone's who's timid and shy as well [...] I mean we probably strike a balance between you know (.) talking about what they talk (.) talking about what (.) you know probably we'd class as the other people's talk because I mean they talk about all sorts of you know (.) there's this lad Kelner who'll talk about nuclear physics or something you know spiel on for hours and the other lot'll talk about how did United do at the weekend and did you see that gorgeous bit of tot or whatever (1.0) so I think we probably (.) you know we talk about some interesting things including some bits in the middle. 
Below, we can see Neil further formulating the nature of his group vis-a-vis the rugby playing 'hard lads'.

NEIL: I mean you could probably draw a list up (.) of what the qualities that make you eligible for [the rugby group] (.) I mean (.) you've probably got to be attractive (.) handsome (.) good at sport (.) physically strong and I'd probably say mentally weak to go along with them [laughter] but I mean you've got to be (.) probably pretty sheepish follow the herd to do that whereas I doubt if one of them would stand out and say something against their whole group whereas one of us lot wouldn't think twice about it

In our eyes, these last extracts stand as a clear instantiation of what Connell (1995) calls complicit masculinity. Neil and his friends are busy trying to differentiate themselves from the hegemonic masculinity of the rugby players, but Neil also distinguishes himself from a subordinated masculine identity: the 'wimp'. But witness the basis upon which this appeal rests: Neil constructs himself as strong. He may not have the muscles of the rugby players, but he does have mental strength. Neil's account trades upon the fact that 
independence is a key theme within the dominant ideologies of masculinity (see Seidler, 1989). 'Being your own man' entails precisely the conviction to follow one's own judgement, and to do what one thinks is right, irrespective of the opinions of others. A dominant value - or hallmark of hegemony - is re-appropriated, even in a moment of resistance.

Carrigan et al.'s (1985) distinction between hegemonic, subordinate and complicit masculinities was forged as a conceptual scheme (although see Connell's, 1995, later life history investigations). Our study sought to put some flesh on the bones, offering a clearer sense of how hegemonic, subordinate and complicit masculinities might manifest in men's everyday lives. But, whereas Connell and colleagues tended to assume that identity positions are relatively fixed and stable for individual men (once hegemonic always hegemonic), the data above demonstrate that these identity positions are by no means stable and consistent. Men are not simply locked into one or another of these categories. Rather, we can see that individual speakers can shift between different modes of masculinity - at one time subordinate, then complicit, then hegemonic too. Acknowledging and working with these kinds of shifts is crucial, we 
argue, for understanding how masculinity works ideologically (we will come back to this point in the second half of the paper).

We can see in the extracts above that 'subject positions' or 'identity positions' are a central feature of discursive practice and ordinary, everyday talk (Davies \& Harré, 1990). As people speak they inevitably formulate a temporary position to speak from, constructing an identity for the moment as part of the discursive flow. Subject positions are often variable, changing rapidly and dynamically depending on the context. Neil, for instance, moves from being a person rather a man, to being a wimp, to being not a wimp but mentally strong and tough, to being in-between, to being an assertive independent individual. Couldn't it be that he is just a bit confused and needs to sort himself out? Can't we, as psychologists, engage in some interpretative work and conclude, perhaps, that all the options Neil runs through are aspects of a complex personality? We don't think so. We know from our interaction with these lads that even Neil's final position in this discussion will be open again to revision (as is always the case in social life) and that these various dilemmas and identity options will be returned to again and again in 
different ways within the 'long conversation' (Maybin, 1996) that mark our lives as social beings.

It is important, we suggest, not to try to pin the butterfly and decide where Neil (or indeed his bête noire the rugby players) 'really' fit in various categorizations of masculinity. Instead, our analysis comes to focus on the patterning of the positions men take up, including the inconsistencies. We become interested in the range, variety, absences and limitations in the cultural resources open to men to negotiate their sense of themselves. Some of the available positions will be highly canonical (i.e. very familiar, clichéd, conventional identity slots), others might be familiar just to small sub-groups of men, or more unique and socially creative, or newly emergent. People usually move across more canonical, more customized, and emergent positions (again, we will come back to these points later as we compare our theory of the social actor with the dominant paradigm).

\section{Negotiating Hegemonic Masculinity}

Our second example stays with the territory of hegemonic masculinity and extends some of the points made above. We focus in 
more detail here on the content of hegemonic, complicit and subordinate masculine modes and show that the characterization of these is also flexible, fluid or 'up for grabs'. The analysis is based upon a different data-set: a series of one-off interviews with around sixty adult men of varying ethnic and social class backgrounds (see Wetherell \& Edley, 1999 for more details). Some were interviewed individually, whereas others were interviewed in pairs or triads. The focus of these discussions was consistent with the previous study, however, centring upon different aspects of their lives and identities as men.

Consider the following extract where Michael, a 26 year old computer software designer and keen amateur boxer, is seen responding to a question about his experiences of feeling gendered.

NE: Okay some people say that (.) you know (.) there's moments in their everyday lives when they feel more masculine than at other times (.) is there anything that either of you could think of (.) erm (.) a time in your life where (.) you know (.) there might have been a particular moment or it might 
be a regular occurring thing you know (.) erm when you have a sense of yourself as masculine

$[\ldots]$

MICHAEL: erm (.) well related to the boxing there's got to be times erm (.) boxing and training that I feel high and confident in my ability (NE: Hm m) and I feel generally wha (.) perhaps what you'd term as erm (.) masculine (.) erm (.) times at work as well (.) a stand-up presentation (NE: Right) erm NE: what is it about that then that gives you that sense MICHAEL: erm (.) the challenge (.) I mean (.) was it yesterday (.) I got up and did a presentation to er (.) 20 or 30 people (.) that was when I went up to [another town] (.) like a sales pitch (.) erm on a technical basis and there was a lot of erm unknown technical ability (NE: hmm) within the (.) within the audience (.) you know the (.) you know on the floor (.) people who had no knowledge of what I was talking about and people that had knowledge that erm (.) in many cases (.) one particular case that equalled mine and I was trying to sell to them that know as much about it as I do (NE: hmm) and you don't know if there's gonna be a question coming up that you can't answer (.) I mean (.) one or two who you feel threatened by (NE: right) purely 
because he's got (.) I know that that guy over there's got as much knowledge of the subject as me (NE: hm m) if he wanted to try and erm (.) knock me down a peg or two (NE: right) if there's anyone in the room who can do it's that guy (.) so you feel threatened by it (.) you feel a bit vulnerable (.) and erm (.) like on the one hand (.) but on the other hand I'm getting up and dictating the flow and making sure the meeting and the presentation's going how I want (NE: hm m) I'm (.) I've got

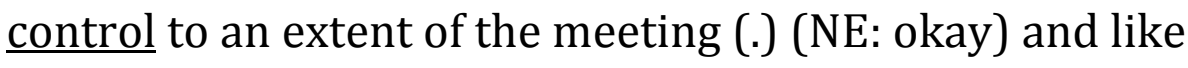
there's a bit of a buzz with that along with a risk

Michael constructs himself as someone who is drawn to the challenge of risky situations, as a person who has the courage or nerve to prevail in such contexts. That is, he appears to be positioning himself, in Carrigan et al.'s (1985) terms, as a hegemonic male. At this moment in time, he seems to be fully investing in this particular subject position. This specific text of identity (Shotter \& Gergen, 1989) is being appropriated as a personal and authentic form of being (see Wertsch, 1991). 
Surprisingly, Michael's classic, 'heroic', hegemonic masculine positioning turned out to be a rather unusual event within our dataset. One might have expected that most of our sample might have claimed and enacted hegemonic masculinity in this kind of way. But an alternative construction was more common which, like Aaron and his friends in the previous example, used macho masculinity as a contrast or counter-point. The next extract presents an example of this. Raj (a 37 year old contract engineer) and John (a 37 years old maintenance engineer) are being asked to compare themselves with various images of men taken from a glossy magazine.

NE: Okay (.) now is there any one of those six images who you would most erm identify with (.) is there anyone there that you would say (.) you know (.) that's most like me JOHN: out of those I'd probably go for four NE: number four (.) Raj (.) what do you think RAJ: yes number four it seems to be (.) NE: okay why him?

JOHN: he looks the most normal (laughs)

RAJ: sorry

JOHN: he looks the most normal I suppose 
RAJ: yes that's right

JOHN: in the dress and (.)

RAJ: yeah half way (.) he's middle of the road

JOHN: I suppose Mr Average you might say (.) yeah

RAJ: mm

NE: okay (.) right so (.) is it true to say then that erm (.) you two both feel (.) or don't have a very strong sense of yourself as being masculine (.) you know (.) it's not a erm (.) a very prominent part of your identity

RAJ: I would say yeah (.) that's my understanding (.) yes (.)

I'm not a masculine man

NE:hm m (.) John (.) what do you think

JOHN: yeah probably the same (.) yeah

NE: yeah

JOHN: I would (.) I would have said averagely so

NE: hm m (.) okay yeah (.) I wasn't saying that you feel that you're unmasculine (JOHN: yeah) but that it's not a very (.) JOHN: what I'm saying is (.) it's not (.) if you took your (.) like your archetypal macho man (.) I'm not there (.) I'm just middle of the road (.) just er (.) average again I suppose 
Both Raj and John present themselves as 'ordinary' men, as 'middle of the road' or 'Mr Average'. For many in our interviews describing themselves as ordinary or normal was an important part of their identity formulations. The macho hero is explicitly invoked and, more implicitly, held up as the epitome of masculinity. But then it gets glossed as an 'archetype'; reformulated as something clichéd, parodic, or less-than-real.

A similar kind of move can be seen in the next extract. Here Greg (a 30 year old brewery manager) constructs himself in clear opposition to the 'stereotype' of macho masculinity, but unlike John and Raj, he doesn't present himself as just an ordinary man. Greg glosses himself, to some extent at least, as something of a maverick figure or gender 'rebel'.

NE: okay (.) what I'd like to start with is erm a comment really about that these discussions are on men and masculinity (.) erm so I'm making a distinction between on the one hand a biological category (GREG: right) and on the other hand something that's a little more tricky or difficult to define (.) so I'd like to start with your ideas on what you think masculinity $\underline{\text { s }}$ 
GREG: mm (.) difficult [...] I don't know what masculinity is (.) I know what it's represented as and if I looked at that I would see the strong erm man (.) very little emotion shown (.) erm really just a strong sort of security figure (.) somebody who's gonna look after the family and the wife erm but predominantly being almost hard to the point of no emotion (NE: right) erm quite a cold description but that (.) that's what it means to me through my sort of socialization process shall I say

NE: hmm (.) okay (.) erm an interesting distinction between what you say masculinity is and what it is represented as (.) what are you trying to keep away from saying GREG: Well if (.) what I believe (.) I think masculinity is represented to me or has been throughout my life as what I've just said (NE: hmm) what I think it is (.) is (.) it's har (.) it's probably very difficult to define (.) I think masculinity is dependent on the individual (.) if that's not a cop out (.) I think each individual could look at it differently (.) I believe masculinity is being myself erm not (.) I've got this nonconformist streak in me from my punk days but not conforming to those stereotypes of masculinity erm if I want a damn good 
cry I'll have a cry and if I want to be supportive of my wife I'll be supporting with my wife (.) if I was (.) you know if my wife had a good job for instance and we decided to have children I'd be quite happy to stay at home and look after the children (.) so I don't think masculinity is (.) is erm (.) is necessarily about being the secure figure (.) being the hard man (.) I don't see it as that way (.) I personally see it as er (.) as a softer sort of image (.) I think it's represented as a different thing totally (.) but my personal opinion is it's a much softer sort of approach

Reading through these last two extracts, it is no easy matter to place Raj, John and Greg into the categories of hegemonic, complicit and subordinate masculinities. At first sight, one might imagine that Greg is assuming a subordinate masculine identity; of someone who is less competitive, more caring and 'in touch' with his emotions. But closer inspection reveals that, similar to Neil (in the previous section), he constructs his rebellious identity using aspects of the dominant ideal. There's more than a hint of machismo in the way that Greg asserts his right to have a 'damn good cry'. Note too the emphasis placed upon independence and individuality. Greg's rejection of macho masculinity is couched as an act (and demonstration) of 'non- 
conformity'. He presents as a man who is determined to be himself. Ironically, therefore, it seems that claims (and displays) of a subordinate masculinity can serve as moves in the construction of more hegemonic identities, just as the (outward) display of machismo can be glossed as undermining its authenticity as an identity for 'ordinary' men. The 'doing', it seems, is always in the detail!

In the space that remains we want to expand further on the analysis of masculinities, identities and ideologies emerging from our work but through a dialogue with an approach that might be more familiar to readers of this journal.

\section{Discursive Psychology and the Gender Role Strain Paradigm: Opening a Dialogue}

As already noted, we take the dominant North American paradigm in the psychology of men and masculinities to consist primarily of forms of quantitative research guided by versions of role theory (Cochran 2010; Levant \& Richmond, 2007). Within this general field we will focus on the gender role strain paradigm developed by Pleck and his 
colleagues (Garnets \& Pleck, 1979; Pleck, 1981; 1995; Thompson \& Pleck, 1986); a widely adopted approach which emerged from critiques of earlier gender role research. It is clear to us that there are a number of points where a discursive psychological framework (hereafter DP) and the Gender Role Strain Paradigm (hereafter GRSP) coincide. Some of these reflect the influence on both approaches of Connell's $(1987 ; 1995)$ powerful sociology of men and masculinities - such as his focus on the plurality of masculinities. This theme was signalled early on in Pleck's $(1981 ; 1995)$ own work. For both GRSP and DP, there are multiple ways of 'being a man', but these are not all equal. The relations between different masculine modes are infused with power and with struggles for normativity and dominance.

Secondly, both DP and GRSP agree that the study of men and masculinities is a political and critical activity. Gender norms, attitudes and identity practices are not neutral but are ideological in their effects. More humanistic perspectives in GRSP focus on increasing general wellbeing, and these sit alongside more radical perspectives challenging male power and the social advantages some men gain from gendered divisions of labour. Levant (2011, p. 766), 
for instance, advocates developing 'positive new visions of how to be a man in today's world, visions that could support the optimal development of men, women and children'. Attention has been paid to the harm traditional masculine roles do, impacting on men's physical and mental health (see Cochran, 2010 for a review). As Levant (2011) notes, the correlates of masculinity often spill catastrophically into the lives of women and children, and into the lives of men who do not follow heteronormative paths.

Thirdly, both DP and GSRP assume a non-essentialist perspective on gender. For both approaches, masculinity is certainly embodied, but neither assumes that this embodiment (i.e. genes, chromosomes and hormones) provides a rigid, universal template and a predictable or inevitable male identity. Increasingly, psychological research on masculinities has moved towards an intersectional view of social identity, derived from black feminist scholarship (see Brah \& Phoenix, 2004 for a review). Researchers have been concerned to document how masculinities interact in complex ways with other identity affiliations, particularly ethnicity and social class (for two recent examples inter alia see Liang et al., 2011; Sanchez et al., 2011). 
Despite these substantial points of agreement, there are other things that seem to divide DP and GRSP. The main differences seem to concern methodology - but this, to us, is no trivial matter, as theory and method go hand-in-hand. We will argue that the ways in which GRSP premises are translated into research impact back on what is assumed about the nature of masculine identities, social action and the workings of ideology. Research within GRSP is mainly quantitative, resulting in more determinate models of the social actor. As we have tried to illustrate, research within DP focuses on investigations of practices that lie outside the psychological laboratory, highlighting the inconsistencies and variability that constitute social life. So the main points of contention between GRSP and DP are inter-related: they concern the degree of situated responsiveness attributed to men's conduct, the formulation of the nature of ideology, and, in addition, the model of the social actor (and social action) that each framework presumes.

\section{Variability and Fixity}

According to Levant and Richmond (2007, p.131) GRSP assumes the acquisition of male gender roles is a variable process. It is 'strongly influenced by prevailing gender ideologies which themselves vary 
according to social location and cultural context.' This claim was central in distinguishing GSRP from earlier gender role identity research. Early theory assumed that male biology and male identities were usually isomorphic. GRSP challenged this, arguing that masculinity norms vary across cultures, generations and sections of society. Different samples of men may share the same biology but may have internalized very different male roles and thus display very different masculine identities.

But is this the limit of variability? Does it only arise between groups of men, in the masculine roles they have internalized? Is GRSP assuming that individual men will be consistent most of the time in their mode of masculinity? The psychometric principles many GSRP researchers follow, and the measuring instruments designed to record adherence, do seem to assume consistency. It is taken for granted that scales such as the MRNI (Male Role Norms Inventory, Levant \& Richmond, 2007), the MGRSS (Masculine Gender Role Stress Scale, Eisler \& Skidmore, 1987) or the GRCS (Gender Role Conflict Scale, O’Neil et al, 1986) measure something (such as adherence, internalization, or conformity) which is trans-situational, repetitive, enduring and predictive of other attitudes, actions or 
personal characteristics. Otherwise, there would be little point in developing the scales or assessing their test-retest reliability.

DP challenges this basic assumption. Investigations of men's accounts in more ecologically valid situations (such as informal discussions or focus groups) quickly demonstrate that an accurate and objective picture must include the variable patterning within each participant as well as across samples or groups of men. We saw above how Neil moves across a number of different formulations. We found that a more traditional hegemonic masculinity and associated set of subject positions are typically mixed together with other regular and recognizable ways of being masculine, and with equivocations, ambivalences and qualifications. Men represent themselves and their situations variably according to the context or situation, in light of accounting work they are attempting to accomplish; in light, that is, of what they are trying to do in the moment as gendered beings.

Psychometric research typically edits out variability in favour of one score for one man on one scale or sub-scale, glossing over the variations in responses which produce these scores, then comparing individual score against individual score, and comparing sample against sample. Our research techniques do not summate or produce 
(an illusory) stability. We attempt to describe the interweaving variable patterns making up what it means to be a man in this situation and the typical range of masculinity repertoires composing cultural 'tool-kits' for doing gendered identity. We are not arguing that individual men are inevitably inconsistent but rather that the forms of regularity, consistency and order in an individual man's gender identity over time are often complex, mixed and fluidly deployed in different situations.

Some might argue that we are being confused here by psychological 'noise' and that variability at the individual level is of no real significance. We think this view is wrong. In what follows we shall press the point that the multiple, fragmented and inconsistent patchwork texture of everyday masculinities in situ is crucial to understanding the social reproduction, ideological force and the actuality of masculine identities. That is not to suggest, of course, that sample results collated across groups of men aren't sometimes valuable, but, to us, these remain abstractions out of context. We would argue that there is no substitute for finer-grain qualitative analysis of the cultural flux and the contingent, emergent and changing forms of social process. 


\section{Formulating Ideology}

Both GRSP and DP agree that masculinities are often ideological. In other words, both recognize that forms of masculinity can serve to maintain and reinforce existing power relations between men and women, and between different groups of men. But what do these ideologies look like in practice and how, precisely, do they operate? The term needs greater specification. It seems to us that GRSP relies on a largely traditional (and cognitive) view of ideology. Here ideology equates with belief systems, attitudes, norms and stereotypes. The assumption is that ideology, made up of discrete blocks of consistent, relatively homogenous, knowledge and representations that become deposited in men's heads, determine their behaviour. Following David and Brannon (1976), GRSP researchers often argue, for example, that traditional masculinity is made up of four belief systems - (i) no sissy stuff; (ii) the importance of being a 'big wheel'; (iii) and a 'sturdy oak'; (iv) while 'giving them hell' (e.g. Levant \& Richmond, 2007, p.131). Similarly, Levant et al. (1992) and Levant and Fischer (1998), when developing their Male Role Norms Inventory (MRNI), deduced that the ideology of traditional masculinity could be summed up in seven theoretically 
derived norms - avoidance of femininity, fear and hatred of homosexuals, self-reliance, aggression, achievement/status, nonrelational attitudes towards sex, and restrictive emotionality.

In line with this 'belief system' view of ideology, the scales and inventories developed within GRSP to assess adherence to traditional masculinity typically present attitudes or normative statements to participants and ask them to agree or disagree. Shepard et al. (2011), for instance, used these statements in their adolescent version of the MRNI - 'a boy should prefer football to sewing'; 'when the going gets tough, boys should get tough'; 'a boy should never reveal his worries to others', and so on. Responding to these statements, however, is not straightforward. A multiplicity of identity affiliations, meanings and understandings are likely to be available. A boy could well decide, for instance, that boys should be like this because society seems to endorse such notions, thus 'strongly agreeing' - and yet, at the same time, think that most boys (including himself) don't behave like this. On a Likert scale there is no room for the live complexities of such acts of identification and interpretation.

In effect, these kinds of procedures deal in 'imaginary identities' (Wetherell, 1986). The scales and inventories construct personae for 
the boy or man to ponder as he undertakes the task. There is a risk that such scales and measuring instruments turn what starts as a construction of traditional masculinity into an authorized reality. That is, such instruments risk perpetrating, reinforcing and ascribing an objective status to views that, in other circumstances, the field of men and masculinities attempts to critique. The boy completing Shepherd et al.'s inventory has been forced to engage with a particular view of masculinity where any sense of the alternatives is occluded or obscured. It seems ironic, if not perverse, that gender researchers keen to document the pervasiveness of traditional masculinity should end up reifying and legitimating that very construct! That's not to imply that our work is immune from such ironies or double binds; but the risks here are more minor - because we begin inductively, documenting the range of resources men draw upon in formulating their identities. Rather than telling boys and men what traditional masculinity consists of and measuring their adherence to that construct, we ask our participants to talk about and puzzle over what they think it is.

Indeed, our theory of the ideological differs from GSRP in a number of key respects. First, we formulate the ideological as an activity 
rather than defined per se as a specific set of ideas or beliefs (Wetherell \& Potter, 1992). Our focus is on men's discursive practices in situations where they are doing identity work. These practices, as men account for and make sense of their activities, may or may not have ideological consequences or effects. That is, they may or may not lead to the maintenance of exploitative social relations and power inequities. The connection is not automatic but depends on political work, further negotiations and the shifting dynamics of the broader social context and social scene. It is complicated, too, by the intersectional nature of identity - that men are not just men but are immersed in social class relations, racialized and so on and so forth.

This is not in any sense to defend 'traditional masculinity'. Instead it is an argument for not deciding on ideological effects in advance of social action and for actually investigating the dynamic activities constituting ideological effects. We want to put the emphasis on researching how, in various contexts, particular masculine practices or modes of accounting and justification work to instantiate patriarchal power. As we argued elsewhere (Wetherell \& Edley, 1999), some of the most powerful men on the planet seem to endorse a kind of mixed or hybrid 'soft or corporate masculinity' and 
occasionally even feminized forms of social action. Tony Blair, John McCain, Barack Obama, David Cameron, Bill Gates, etc. might score quite lowly on a traditional masculinity scale, yet can we be confident, as a result, that their standpoints will be anti-patriarchal?

Second, a focus on the cognitive (beliefs, norms, attitudes) misses other crucial aspects of how men's power is maintained. Ideology is not just about beliefs. We also need ways of investigating affective, emotional, interactional and relational practices (Wetherell, 2012) as well as patterns of embodiment. For example, in the 1970s, Marianne Wex documented, through a simple but dramatic series of photographs of ordinary people in everyday scenes, how men typically take up more public space (with legs apart and arms akimbo) and how women confine their bodies to fit. Arguably, male power is carried more effectively, not through belief systems, but via forms of embodied action.

Finally, in contrast to GRSP, ideology for DP does not present in large, consistent clumps with four or perhaps seven elements making up the belief system that sustains male power. Like Michael Billig and his colleagues (1988, see also Wetherell \& Potter, 1992), we have nearly always found that discursive practices are best described as 
forming an inconsistent and fragmented patchwork. In their responses to feminism, for instance, we found men move backwards and forwards across a complicated discursive terrain made up of arguments about the rightness of equality, repertoires invoking various 'practical considerations' that seem to demand a limit to equality, repertoires in admiration of activists, to strictures that they should not go 'too far', and so on (see Edley \& Wetherell, 2001). Claims for moderation dynamically and flexibly collide with respect for commitment, 'in principle' arguments collide with 'in practice' arguments, feminists are divided into various acceptable and unacceptable categories - but in such a way that so often seems to sustain the status quo. Our point is that the maintenance of power occurs directly and often very effectively as a result of this fragmented, mobile and inconsistent discursive scene but also that, over time, this is how social change and new cultural notions come about. In other words, this is what social reproduction actually looks like, rather than the steamrollering repetition of a belief system by 'social dopes' who reproduce ideology like the sound of a stuck record.

The Model of the Social Actor and Social Action 
In the last few decades, the psychology of men and masculinities has decisively rejected older ideas of masculinity as an inherent potential which develops naturally into a stable masculine identity or male personality exhibiting sex-typed traits (Cochran, 2010). As noted, GRSP theorists argue instead that masculinities arise from conformity to cultural norms and gender ideologies. Masculinity is thus not predictable from biology per se, and identity outcomes are more varied than either the option of 'successfully socialized male man' or his 'deviant' counter-part. Nonetheless, many problematic elements of older trait-type analyses of the social actor still seem to persist in GRSP. Is the masculine male of early gender research exhibiting sex-typed personality traits so very different from the man in GRSP research conforming to internalized cultural beliefs about traditional masculine roles? Both appear as solid citizens, and, in their own way, both appear to be monomaniacs. Assumptions about the origins of masculinity may have changed, but the view of the social actor remains pretty much the same. In most GRSP scholarship, masculinity remains a relatively stable property of the individual. Like the earlier work, it assumes little internal change and a great deal of individual predictability. As a consequence, the socio- 
psychological processes involved in conforming to this internalized belief system remain obscure. Psychologically speaking, how does this internalization work? Do men actively consult cultural scripts lined up in their heads to work out what to do in any given situation, or is it more like Solomon Asch's famous conformity studies where people go along with the majority in spite of their own values and judgments? Alternatively, does adhering to traditional masculinity just come naturally and automatically after a while?

GSRP adopts role theory, but much of role theory is actually deeply antithetical to trait/type psychology and to the individualism that seems to persist in the psychology of men and masculinities (Edley \& Wetherell, 1995, ch. 3; Connell, 1995). Erving Goffman (1959), for example, argued that roles were performances, highly dependent on the patterning of social interaction. In this sense, roles are not in individuals' heads, as internalized scripts to be consulted, but require collaborative instantiation and the inter-subjective ordering of social situations. Bringing a role to life involves displaying oneself as a particular kind of person and coordinating with others who are simultaneously displaying their own readings of the situation and the identities at stake. Continuing the theatrical analogy, Goffman argued 
that actors have 'stagecraft' and learn various acting techniques. He was interested in describing some of these features in people's everyday performances. He emphasized that roles are something actively realized. Social actors are constrained by social structure and the ordering of social situations; but they are also agents. In the hands of later ethnomethodologists (e.g. Kessler \& McKenna, 1978; West \& Zimmerman, 1987; 2009) such insights led to fascinating work on, for example, how transgender individuals learn to perform a new gender afresh; how they acquire a new stagecraft, so to speak. Besides conformity to internalized scripts, a great deal else is required to enact 'traditional masculinity'. Our own work on masculine identities is more commensurate with these performative and ethnomethodological readings of how roles work psychologically.

In conclusion therefore, we would argue that a DP approach to theorizing and analyzing men and masculinities offers a number of distinct advantages over its GRSP counter-part. In paying close attention to how men talk about themselves (and others) as men, we gain a clearer sense of how masculinities are created, negotiated and deployed. As we have tried to illustrate, the picture here is one of dynamism and complexity. Any attempt to pin men down or to 
classify them into types is usually frustrated. However, in embracing this complexity, not only do we gain a better (and more ecologically valid) feel for the texture of social life, but we also end up with a stronger understanding of how gender hierarchies are constructed, unsettled and sustained.

\section{Appendix: Transcription Notation}

The following transcription notation represents a simplified version of that developed by Gail Jefferson (see Atkinson \& Heritage (1984) for a more comprehensive account).

(.) Short pause of less than 1 second.

(1.0) Timed pause (in seconds).

[...] Material deliberately omitted.

[text] Clarificatory information.

text Word(s) emphasized.

\section{Footnote}

1. We would like to thank Ron Levant, not least for his kind invitation to write a piece on the Discursive Psychology of men and masculinity, and also the various anonymous 
reviewers for their constructive comments on the earlier drafts of this paper.

\section{References}

Antaki, C. and S. Widdicombe (eds) (1998) Identities in Talk. London: Sage.

Atkinson, J.M. and J.C. Heritage (1984) (eds) Structures of Social Action: Studies in Conversation Analysis. Cambridge: Cambridge University Press.

Billig, M., S. Condor, D. Edwards, M. Gane, D. Middleton and A.

Radley (1988) Ideological Dilemmas: A Social Psychology of Everyday Thinking. London: Sage.

Billig, M. (1991) Ideology and Opinions: Studies in Rhetorical Psychology. London: Sage.

Brah, A. and Phoenix, A. (2004) Ain't I a Woman? Revisiting Intersectionality. Journal of International Women's Studies. 5 (3), 75-86. 
Brannon, R. (1976) 'The male sex role: our culture's blueprint of manhood, and what it's done for us lately' in D. David and R. Brannon (eds) The Forty-Nine Percent Majority: The male sex role. Reading, M.A: Addison-Wesley.

Carrigan, T., R.W. Connell and J. Lee (1985) Towards a new sociology of masculinity. Theory and Society, 14, 551-604.

Cochran, S. V. (2010). 'Emergence and development of the psychology of men and masculinity' in Chrisler, J. C. \& McCreary, D. R. (eds.) Handbook of Gender Research in Psychology. Volume 1: Gender Research in General and Experimental Psychology (pp. 4358). New York: Springer.

Connell, R.W. (1987) Gender and Power. Cambridge: Polity.

Connell, R.W. (1995) Masculinities. Cambridge: Polity.

Davies, B. and R. Harré (1990) Positioning: The Discursive Production of Selves. Journal for the Theory of Social Behaviour, Vol. 20, 43-65. 
Dixon, J. and Wetherell, M. (2004) 'On discourse and dirty nappies: Gender, the division of labour and the social psychology of distributive justice'. Theory and Psychology, 14 (2), 167-189.

Edley, N. (2001) 'Analysing Masculinity: Interpretative Repertoires, Ideological Dilemmas and Subject Positions' in M. Wetherell, S. Taylor and S.J. Yates (eds) Discourse as Data: A Guide to Analysis. London: Sage and the Open University. (pgs 189-228)

Edley, N. (2002) 'The loner, the walk and the beast within: Narrative fragments in the construction of masculinity' in W. Patterson (ed.) Strategic Narrative: new perspectives on the power of stories. Oxford: Lexington. (pgs 127-145).

Edley, N. (2006) Never the Twain Shall Meet: A Critical Appraisal of the Combination of Discourse and Psychoanalytic Theory in Studies of Men and Masculinity. Sex Roles, 55, 601-608.

Edley, N. and Wetherell, M. (1995) Men in Perspective: Practice, Power and Identity. Hemel Hempstead: Prentice Hall. 
Edley, N. and Wetherell, N. (1996) 'Masculinity, power and identity.' In Mac an Ghaill, M. (ed.) Understanding Masculinity. Milton Keynes: Open University Press.

Edley, N. and M. Wetherell (1997) 'Jockeying for Position: the construction of masculine identities' Discourse and Society 8 (2): 203-17.

Edley, N. and Wetherell, M. (1999) ‘Imagined futures: Young men's talk about fatherhood and domestic life'. British Journal of Social Psychology, 37, 181-195.

Edley, N. and Wetherell, M. (2001) 'Jekyll and Hyde: Analysing constructions of the feminist'. Feminism and Psychology, 11 (4), 439-457.

Edley, N. and Wetherell, M. (2008) ‘Discursive psychology and the study of gender: A contested space.' In K. Harrington, L. Litosseliti, H. Saunston and J. Sunderland (eds.) Gender and Language: Theoretical and Methodological Approaches. Basingstoke: Palgrave. 
Edwards, D. 1997. Discourse and Cognition. London: Sage.

Eisler, R.M. and Skidmore, J.R. (1987) Masculine gender role stress: Scale development and component factors in the appraisal of stressful situations. Behavior Modification, 11, 123136.

Frosh, S., Phoenix, A. and Pattman, R. (2000) 'But it’s racism I really hate': Young masculinities, racism and psychoanalysis. Psychoanalytic Psychology, 17, 225-242.

Frosh, S., Phoenix, A. and Pattman, R. (2002) Young Masculinities. Basingstoke: Palgrave.

Garnets, L. and Pleck, J.H. (1979) Sex role identity, androgyny, and sex role transcendence: A sex role strain analysis. Psychology of Women Quarterly, 3, 270-283.

Gill, R., Henwood, K. and MacLean, C. (2005) Body projects and the regulation of normative masculinity, Body and Society, 11 (1), 37-62. 
Goffman, E. (1959) The Presentation of Self in Everyday Life. New York: Doubleday Anchor.

Gough, B. (2009) A psycho-discursive approach to analysing qualitative interview data, with reference to a father-son relationship, Qualitative Research, 9[5]: 527-545

Gough, B. \& Robertson, S. (2009) (Eds) Men, Masculinities and Health: Critical perspectives. Basingstoke: Palgrave

Hall, M. \& Gough, B. (2011) Magazine and reader constructions of 'metrosexuality' and masculinity: A membership categorisation analysis, Journal of Gender Studies, 20[1]: 69-87 Hall, M., Gough, B., Seymour-Smith, S. (2012) 'I'm METRO, NOT gay', a discursive analysis of men's make-up use on YouTube, Journal of Men's Studies, 20 (3), 209-226.

Henwood, K.L. and Procter, J. (2003). "The 'good father': Reading men's accounts of paternal involvement during the transition to 
first time fatherhood". British Journal of Social Psychology, 42, 337-355.

Henwood, K., R. Gill and C. McLean (2001) 'The Changing Man', The Psychologist: Special Issue on the Body April (Leicester: BPS).

Kessler, S. and W. McKenna (1978) Gender: An

Ethnomethodological Approach. New York: Wiley.

Kimmel, M. (1987) Changing Men: New Directions in the Study of Men and Masculinity. Newbury, CA: Sage

Korobov, N. (2004) Inoculating against prejudice: A discursive approach to homophobia and sexism in adolescent male talk. Psychology of Men and Masculinity, 5 (2), 178-190.

Korobov, N. and Bamberg, M. (2004) Positioning a 'mature self' in interactive practices: How adolescent males negotiate physical attraction in group talk. British Journal of Developmental Psychology, 22 (4), 471-492. 
Levant, R. F. (2011). Research in the psychology of men and masculinity using the gender role strain paradigm as a framework. American Psychologist, 66, 762-776.

Levant, R.F. and Fischer, J. (1998) The male role norms inventory. In C.M. Davis, W.H. Yarber, R. Bauserman, G. Schreer and S.L. Davis (eds.) Sexuality-Related Measures: A Compendium. $\left(2^{\text {nd }}\right.$ Edition, pp. 469-472). Newbury Park, CA: Sage.

Levant, R.F., Hirsch, L., Celentano, E., Cozza, T., Hill, S., MacEachern, et al. (1992) The male role: An investigation of norms and stereotypes. Journal of Mental Health Counselling, 14, 325-337.

Levant, R. F. \& Richmond, K. (2007). A review of research on masculinity ideologies using the Male Role Norms Inventory. Journal of Men's Studies, 15, 130-146.

Liang, C.T.H., Salcedo, J. and Miller, H.A. (2011) Perceived racism, masculinity ideologies, and gender role conflict among Latino men. Psychology of Men and Masculinity, 12 (3), 201-215. 
Mahalik, J. R., Locke, B. D., Ludlow, L. H., Diemer, M. A., Scott, R. P., Gottfried, M., \& Frietas, G. (2003). Development of the Conformity to Masculine Norms Inventory. Psychology of Men and Masculinity, Vol. 4, 3-25

Maybin, J. (1996). 'Story Voices: The Use of Reported Speech in Ten to Twelve Year Olds' Spontaneous Narratives.' Current Issues in Language and Society 3 (1):36-48.

Nentwich, J. (2008) New Fathers and Mothers as Gender Troublemakers? Exploring Discursive Constructions of Heterosexual parenthood and their Subversive Potential. Feminism and Psychology, 18, 207-230.

O’Neil, J.M., Helms, B., Gable, R., David, L. and Wrightsman, L. (1986) Gender role conflict scale: College men's fear of femininity. Sex Roles, 14, 335-350.

Phoenix, A. and Frosh, S. (2001) Positioned by 'Hegemonic' Masculinities: A Study of London Boys' Narratives of Identity. Australian Psychologist, 36 (1), 27-35. 
Pleck, J. H. (1981) The myth of masculinity. Cambridge, MA: MIT Press.

Pleck, J.H. (1995) The gender role strain paradigm: An update. In R.F. Levant and W.S. Pollack (eds.) A New Psychology of Men. New York: Basic Books.

Potter, J. and Wetherell, M. 1987. Discourse and Social Psychology: Beyond Attitudes and Behaviour. London: Sage.

Reckwitz, A. (2002) 'Toward a Theory of Social Practices: A Development in Culturalist Theorizing,' European Journal of Social Theory 5 (2): 243-263.

Riggs, D.W. (2010). What about the children! Masculinities, sexualities and hegemony. Cambridge: Cambridge Scholars Press.

Said, E. (1978) Orientalism. Harmondsworth: Penguin.

Sanchez, F.J., Liu, M.W., Leathers, L. and Goins, J. (2011) The subjective experience of social class and upward mobility among 
African American men in graduate school. Psychology of Men and Masculinity, 12 (4), 368-382.

Schatzki, T.R., Knorr-Cetina, K. and von Savigny, E. (eds.) (2001) The Practice Turn in Contemporary Theory. London: Routledge.

Seidler, V.J. (1989) Rediscovering Masculinity: Reason, Language and Sexuality. New York: Routledge.

Seymour-Smith, S. (2008) 'Blokes don't like that sort of thing': men's negotiation of a 'troubled' self-help group identity. Journal of Health Psychology, 13 (6), pp. 785-797.

Seymour-Smith, S. (2013) A reconsideration of the gendered mechanisms of support in online interactions about testicular implants: a discursive approach. Health Psychology, 32 (1, Special Issue: Men's Health: Masculinity and Other Influences on Male Health Behaviors), pp. 91-99.

Seymour-Smith, S. and Wetherell, M. (2006) “'What he hasn't told you ...": Investigating the micro politics of gendered support 
in couples co-constructed accounts of illness'. Feminism and Psychology, 16 (1), 105-127.

Seymour-Smith, S., Wetherell, M. and Phoenix, A. (2002) “"My wife ordered me to come!": A discursive analysis of doctors' and nurses' accounts of men's use of general practitioners'. Journal of Health Psychology, 7 (3), 253-267.

Shepard, S.J., Nicpon, M.F., Haley, J.T., Lind, M. and Liu, W.M. (2011) Masculine norms, school attitudes and psychosocial adjustment among gifted boys. Psychology of Men and Masculinity, 12 (2), 181-187.

Shotter, J. and K.J. Gergen (1989) (eds) Texts of Identity. London: Sage.

Speer, S. (2005) Gender Talk: Feminism, Discourse and Conversation Analysis. London: Routledge.

Staunaes, D. (2005) From culturally avant-garde to sexually promiscuous: Troubling subjectivities and intersections in the 
social transition from childhood to youth. Feminism and Psychology, 15 (2), 149-167.

Staunaes, D. (2009) 'I am right behind him': Managing fear and boys in the time of the Danish Cartoon Crisis. In J. Hearn, M. Lykke and A.Phoenix (eds.) Intersectionalities, Power and Identity. London: Routledge.

Terry, G. and Braun, V. (2009) 'When I was a bastard':

Constructions of masculinity in men's accounts of maturity. Journal of Gender Studies, 18 (2), 115-178.

Terry, G. and Braun, V. (2011) 'Its kind of me taking responsibility for these things': Men, vasectomy and contraceptive economies. Feminism and Psychology, 21 (4), 475495.

Terry, G. and Braun, V. (2013) 'We have friends, for example, and he will not get a vasectomy': Imagining the self in relation to others when talking about sterilisation. Health Psychology, 32 (1), 100-109. 
Thompson, E.H. and Pleck, J.H. (1986) The structure of male role norms. American Behavioral Scientist, 29, 531-543.

Toerin, M. and Durrheim, K. (2001) Power through knowledge: Ignorance and the 'Real man'. Feminism and Psychology, 11 (1), $35-54$.

Vandello, J.A. and Bosson, J.K. (2012) Hard won and easily lost: A review and synthesis of theory and research on precarious manhood. Psychology of Men and Masculinities, 14 (2), 101-113.

Wertsch, J.W. (1991) Voices of the Mind: A socio-cultural approach to mediated action. London: Harverster Wheatsheaf.

West, C. and Zimmerman, D.H. (1987) Doing gender. Gender and Society, 1, 125-51.

West, C. and Zimmerman, D.H. (2009) Accounting for doing gender. Gender and Society, 23 (1), 112-122.

Weatherall, A. (2002) Gender, Language and Discourse. London: Routledge. 
Wetherell, M. (1986) Linguistic repertoires and literary criticism: New directions for a social psychology of gender. In S. Wilkinson (ed.) Feminist Social Psychology: Developing Theory and Practice. Milton Keynes: Open University Press.

Wetherell, M. (1996) 'Life histories/social histories'. In Wetherell, M. (ed.) Identities, Groups and Social Issues. London: Sage.

Wetherell, M. (1998) 'Positioning and interpretative repertoires: Conversation analysis and post-structuralism in dialogue'. Discourse and Society, 9 (3), 431-456.

Wetherell, M. (2003) 'Paranoia, ambivalence and discursive practices: Concepts of position and positioning in psychoanalysis and discursive psychology'. In R. Harre and F. Moghaddam (eds.) The Self and Others: Positioning Individuals and Groups in Personal, Political and Cultural Contexts. New York: Praeger/Greenwood. 
Wetherell, M. (2012) Affect and Emotion: A New Social Science Understanding. London: Sage.

Wetherell, M. and Edley, N. (1998) 'Gender practices: Steps in the analysis of men and masculinities.' In Henwood, K., Griffin, C. and Phoenix, A. (eds.) Standpoints and Differences: Essays in the Practice of Feminist Psychology. London: Sage.

Wetherell, M. and N. Edley (1999) 'Negotiating Hegemonic Masculinity: Imaginary Positions and Psycho-Discursive Practices'. Feminism \& Psychology, Vol. 9 (3): 335-356.

Wetherell, M. and Edley, N. (2008) 'Masculinity manoeuvres: Critical discourse psychology and the analysis of identity strategies'. In N. Coupland and A. Jaworski (eds.) The New Sociolinguistics Reader. Basingstoke: Palgrave.

Wetherell, M. and Potter, J. (1992) Mapping the Language of Racism: Discourse and the Legitimation of Exploitation. London and New York: Harvester Wheatsheaf and Columbia University Press. 
Wex, M. (1979) Let's Take Back Our Space. Hamburg and Longmead, Dorset: Element Books. 